\title{
HIGHER CIGARETTE TAXES - HEALTHIER PEOPLE, WEALTHIER STATE: THE HUNGARIAN EXPERIENCE
}

\author{
Tibor Szilágyi \\ Consultant, tobaco control, Hungary
}

\begin{abstract}
SUMMARY
Objective: To prove that higher cigarette taxes eventually decrease smoking and do also increase state incomes from tobacco taxes by using Hungarian figures.

Method: Collection and analysis of available data on tobacco use, levels of excise and value added taxes on tobacco products and state incomes originating from the tobacco sector.

Conclusions: In Hungary, regular tobacco tax increases resulted in decreased cigarette consumption and its lower prevalence figures in some population groups. State incomes have increased in spite of regular cigarette tax raises. Therefore, there is on conflict of interest between the health and finance portfolios in supporting further tobacco tax increases. Hungary should use regular, above the inflation tobacco tax raises as means for improving population health. Tobacco control advocates should prevent tobacco companies' attempts aimed at deterring decision makers from supporting such tax policies.
\end{abstract}

Key words: Hungary, smoking, taxation, cigarette consumption

Address for correspondence: T. Szilágyi, 65 Áfonya st, H-2030 Érd, Hungary. E-mail: h21hf@axelero.hu

\section{INTRODUCTION}

Raising tobacco taxes is highly effective in reducing the demand for tobacco products (1), and consequently, reduces smoking-related costs imposed on societies, improves population health. Higher taxes raise additional revenues for the state budget. According to the World Bank, regular tax raises, should they exceed the level of inflation and real wage increases, are today the most effective measure to reduce tobacco use, especially among the youth and low income smokers.

Tobacco use is the most important behaviour-related cause of deaths in Hungary. Out of around 2.6 million adult Hungarian smokers - for a population of 10 million - more than 22,000 people aged 35 and over died because of smoking in 2004. In addition to that more than 2,300 people died because of passive smoking (2).

Tobacco-related morbidity and mortality can also be expressed in economical terms. The burden imposed by smoking on the Hungarian society (external costs) is heavy. In 2004, Hungary lost nearly 400 billion Hungarian Forints (HUF) (or $€ 1.6$ billion) in relation to people's smoking or $1.7 \%$ of its gross domestic product (GDP), exceeding the average loss of countries of the European Union (EU) (1.04-1.39\%) (3).

The EU regulates the taxation of tobacco products via directives, the most relevant of which being Council Directive 2002/10/EC of 12 February 2002. Directives set the tax structure and rates of excise duties to be applied on manufactured tobacco (4). In May 2006 the majority of countries which joined the EU in 2004 still fell short from complying with EU rules (5). All of them negotiated transition periods of various lenghts (until 2007-2010).

The need for introducing EU tax levels - along with the recommendation of the WHO Framework Convention on Tobacco Control (FCTC, Article 6) indicating that countries should use price policies in a way to have an impact on health - helped new Member States in designing their tobacco tax policies. In the last few years Hungary has made substantial efforts to reach EU tax levels, including a 35\% tax raise in 2004 (6).

\section{SOURCES OF DATA}

Prevalence figures have been obtained from the Hungarian Gallup Institute. Cigarette consumption figures originate from the Central Statistical Office (CSO). Taxation data and information on the state budget have been obtained from the Ministry of Finance (MoF) via GKI Economic Research Institute (GKI). Smokingrelated mortality data also originate from the GKI (2).

\section{MAIN FINDINGS}

\section{State Revenues from the Tobacco Sector}

Tobacco use generates revenue for the state budget. This materializes in the form of different consumption-related taxes, but also includes local and corporate taxes and social insurance payments for industry employers. As Table 1 indicates, the most substantial share of this revenue is excise tax. 
Table 1. State incomes from tobacco manufacturers, 2004 (Source: GKI, using data from: ${ }^{*} \mathrm{MoF},{ }^{* *} \mathrm{CSO}$ )

\begin{tabular}{|l|c|}
\hline Type of income & Amount (billion HUF) \\
\hline Excise tax* & 187.1 \\
\hline VAT** $^{*}$ & 68.8 \\
\hline Corporate tax paid by tobacco companies & 0.41 \\
\hline Social security payments by tobacco companies & 3.6 \\
\hline $\begin{array}{l}\text { Total state revenue from tobacco } \\
\text { manufacturers }\end{array}$ & $\mathbf{2 5 9 . 9}$ \\
\hline
\end{tabular}

The Hungarian state budget is not dependent on the revenues from the tobacco sector. In 1999 only 3\% of total tax revenues originated from this sector; in Romania tobacco companies provide $12 \%$, in Turkey and Ukraine $11 \%$, in Poland $7 \%$ of the overall tax income of the general budget (7).

\section{Taxation of Tobacco Products}

Since 1991 a three-tiered tax is levied on tobacco products in Hungary, resembling the tax structures of the majority of European countries. The "specific tax" (ST) is levied on 1,000 cigarettes, while the "ad valorem tax" (AVT) represents a given percent of the consumer price. These two forms are the components of the excise tax. In addition to these, a value added tax (VAT) is applied to tobacco products (25\% until 31 December 2005, 20\% from 1 January 2006).
Since early 90 s tobacco excises have been regularly increased. (Table 2) Excise revenues increased in parallel with the increases in tax levels: state incomes from tobacco taxation increased more than three times between 1998 and 2005, while the collected VAT has more than doubled in the same period.

The yearly average excise income increase between 1993 and 2005 is $18.7 \%$. Tax increases always resulted in higher budget incomes, except for the year 2004. This feature has got several explanations. Table 2 line 2004 shows the sharp increase in both the ST and AVT levels.

Also, tobacco companies launched immediate counter-measures, which, as a secondary effect, have decreased the collected tax (such as introduction of new, low priced "discount" brands, and the launch of a "price war", meaning the strategic use of pricing).

For example, Philip Morris decreased prices of its mediumpriced brands just on the day when other companies raised their prices. Soon, BAT followed suit in cutting its prices back. Table 2 also indicates that the price of BAT's Sopiane brand (the leading brand in the MPPC) has been lower in 2005 than in 2004.

New packages with only 19 cigarette sticks instead of 20 have been designed for the majority of brands. This made possible a (pseudo) decrease or stagnation of the price.

\section{Affordability and Price Elasticity}

The relation between wages and cigarette prices refers to the affordability. The more affordable cigarettes are the less impact a tax raise might have on their consumption. Table 3 indicates that in the case of MPPC (this might not be the case for all brands) affordability decreased between 1995-2005. In 2005, smokers

Table 2. Excise revenues from cigarettes, cigarette prices and excise levels, 1992-2006. (Source: Dr Judit Barta, GKI)

\begin{tabular}{|c|c|c|c|c|c|c|c|}
\hline \multirow[b]{2}{*}{ Year } & \multirow{2}{*}{$\begin{array}{l}\text { Collected consumption/ } \\
\text { excise tax (VAT excluded, } \\
\text { billion HUF) }\end{array}$} & \multirow[b]{2}{*}{$\begin{array}{c}\text { Collected VAT } \\
\text { (billion HUF) }\end{array}$} & \multirow{2}{*}{$\begin{array}{c}\text { Tax increase } \\
\text { in } \%, \text { previous } \\
\text { year }=100 \%\end{array}$} & \multirow{2}{*}{$\begin{array}{c}\text { Price/pack } \\
\text { (most popular } \\
\text { price category, } \\
\text { MPPC) }\end{array}$} & \multirow{2}{*}{$\begin{array}{l}\text { Price increase } \\
\text { in the MPPC cat- } \\
\text { egory, previous } \\
\text { year }=100 \%\end{array}$} & \multicolumn{2}{|c|}{ Excise tax levels } \\
\hline & & & & & & $\begin{array}{c}\text { ST (HUF/1,000 } \\
\text { cigarettes) }\end{array}$ & AVT (\%) \\
\hline 1992 & 24.9 & & - & 47.20 & - & 770 & 50 \\
\hline 1993 & 31.1 & & 124.9 & 60.40 & 128 & 920 & 50 \\
\hline 1994 & 34 & & 109.7 & 73.50 & 121.6 & $\begin{array}{l}\text { I-VI } 1020 \\
\text { VII-X } 1120 \\
\text { XI-XII } 1210\end{array}$ & $\begin{array}{l}50 \\
50 \\
65\end{array}$ \\
\hline 1995 & 43.7 & & 128.5 & 86.40 & 117.5 & 1210 & 65 \\
\hline 1996 & 47 & & 107.5 & 115 & 133.1 & 1390 & 75 \\
\hline 1997 & 57.8 & & 123 & 139 & 120.8 & 1560 & 75 \\
\hline 1998 & 68.6 & 33.8 & 118.7 & 169 & 121.6 & $\begin{array}{l}\text { I-VIII } 1725 \\
\text { IX-XII } 1950\end{array}$ & $\begin{array}{l}75 \\
17^{\star}\end{array}$ \\
\hline 1999 & 98.6 & 39.6 & 143.7 & 198 & 117.1 & 1950 & 17 \\
\hline 2000 & 102.5 & 45.6 & 104 & 228 & 115.1 & 2300 & 17 \\
\hline 2001 & 111.8 & 51.6 & 109 & 258 & 113.1 & 2645 & 17 \\
\hline 2002 & 126.5 & 55.8 & 113.1 & 310 & 120.1 & 4200 & 18 \\
\hline 2003 & 221.2 & 72.6 & 174.9 & 341 & 110 & 4950 & 20 \\
\hline 2004 & 187.1 & 82.2 & 84.6 & 450 & 120.5 & 6450 & 23 \\
\hline 2005 & 191.8 & 86.6 & 102.5 & 440 & 105.3 & 6450 & 23 \\
\hline 2006 & & $\begin{array}{l}76.7 \\
(I-V I)\end{array}$ & & $\begin{array}{l}460 \\
(I-V I)\end{array}$ & $\begin{array}{l}106.2 \\
(I-V I)\end{array}$ & $\begin{array}{l}\text { I-VIII } 6880 \\
\text { IX-XII } 7240\end{array}$ & 27.5 \\
\hline
\end{tabular}

${ }^{*}$ As of this year AVT given as a \% of retail price. 
Table 3. Affordability of cigarettes (1995-2005) (Source: Hana Ross, calculation provided with the data from the author)

\begin{tabular}{|l|c|c|c|}
\hline Year & $\begin{array}{c}\text { Net average } \\
\text { monthly income }\end{array}$ & $\begin{array}{c}\text { Retail price of } \\
\text { a pack of MPPC } \\
\text { (HUF/pack) }\end{array}$ & $\begin{array}{c}\text { Nr of packs which } \\
\text { can be bought } \\
\text { using the monthly } \\
\text { income }\end{array}$ \\
\hline 1995 & 25,891 & 86.4 & 300 \\
\hline 1996 & 30,544 & 115 & 266 \\
\hline 1997 & 38,145 & 139 & 274 \\
\hline 1998 & 45,162 & 169 & 267 \\
\hline 1999 & 50,076 & 198 & 253 \\
\hline 2000 & 55,785 & 228 & 245 \\
\hline 2001 & 64,915 & 258 & 252 \\
\hline 2002 & 77,607 & 310 & 250 \\
\hline 2003 & 88,467 & 341 & 259 \\
\hline 2004 & 93,715 & 450 & 208 \\
\hline 2005 & 103,134 & 440 & 234 \\
\hline
\end{tabular}

could have bought $22 \%$ less packs of MPPC cigarettes that they have been able doing in 1995; in the same period the real price of a pack of MMPC slightly increased (by $0.75 \%$ ) (8).

There is a different situation with Marlboro; the real price of this brand decreased by $6.65 \%$ between $1990-2000$ (8).

Table 2 also shows that there were two years in which the number of cigarette packs purchasable from the average wage dropped significantly: 1996, when the so-called Bokros-package (9) of economic measures have been introduced which resulted in the decrease of consumption of various goods, especially luxury goods; and 2004, when a sharp increase in tax levels was implemented.

\section{Impact on Tobacco Use}

Table 4 indicates that when prices go up (legal) cigarette consumption goes down. In spite of decreased consumption total spending on cigarettes increased, which resulted in higher tax revenues.

There were different reactions from Hungarian smokers to tax/price increases, such as: smoking less, quitting for good, changing to other tobacco products (e.g. downgrading to cheaper

Table 4. Cigarette prices, sales and amount spent on tobacco products (Source: Dr Judit Barta, GKI)

\begin{tabular}{|l|c|c|c|c|}
\hline Year & $\begin{array}{c}\text { Retail price } \\
\text { of a pack of } \\
\text { MPPC (HUF) }\end{array}$ & $\begin{array}{c}\text { No. of cigarettes } \\
\text { sold legally } \\
\text { (billion pieces) }\end{array}$ & $\begin{array}{c}\text { No. of cigarette } \\
\text { packs (of 20) } \\
\text { sold legally } \\
\text { (billion packs) }\end{array}$ & $\begin{array}{c}\text { Turnover } \\
\text { (billion HUF) }\end{array}$ \\
\hline 1998 & 169 & 21,415 & 1.07 & 180.8 \\
\hline 1999 & 198 & 24,266 & 1.21 & 239.6 \\
\hline 2000 & 228 & 21,968 & 1.1 & 250.8 \\
\hline 2001 & 258 & 19,940 & 0.997 & 257.2 \\
\hline 2002 & 310 & 19,006 & 0.95 & 294.5 \\
\hline 2003 & 341 & 19,715 & 0.985 & 335.9 \\
\hline 2004 & 450 & 15,628 & 0.781 & 351.4 \\
\hline
\end{tabular}

or to using raw, cut tobacco to prepare home made cigarettes) or turning to the illegal market.

In 1999 a survey by the Fact Institute of Applied Sciences price increases ranked 5 th on the list of determinants which might have an influence on the chance of smoking habit, preceding factors like contracting a smoking-related disease, the advice of a medical doctor or concerns for the own and the family members' health (10).

Both sales statistics (performed yearly by the CSO) (Table 4) and smoking prevalence surveys indicate that smokers are ready to change their smoking habits in response to various tobacco control interventions, price increases falling among those with the highest impact.

Prevalence data published by the Hungarian Gallup Institute (11) indicate that while smoking prevalence among men remained quite stable between 1995-2004, women tend to smoke less, with significant decreases in smoking prevalence figures in the 25-49 age groups between 2000 and 2004 (Fig. 1).

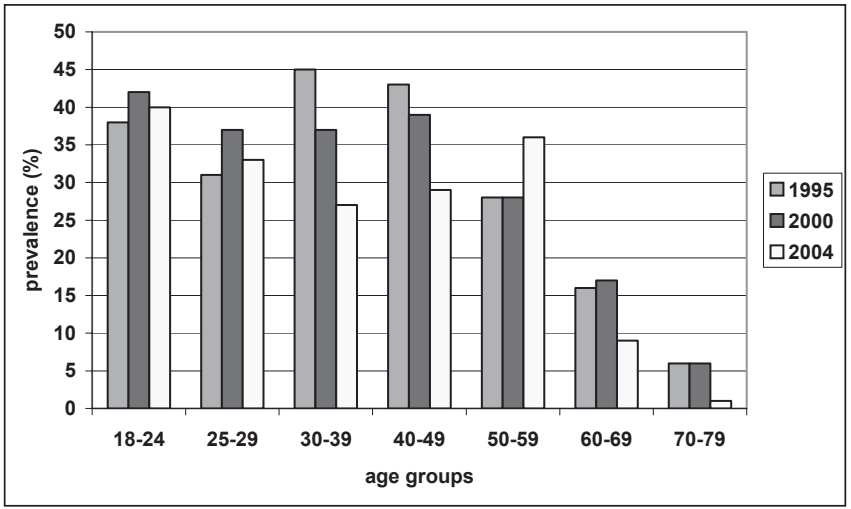

Fig. 1. Smoking prevalence among women in 1995, 2000 and 2004

(Source: Hungarian Gallup Institute)

A 2006 Gallup-survey (12) indicated that while there was no further decrease in smoking prevalence between 2004 and 2006, smokers tend to smoke less (Fig. 2). In the majority of age groups daily cigarette consumption decreased. The decrease, again, has been more pronounced among women. Using data presented in Fig. 2 it can be calculated that between 2004 and 2006 adult

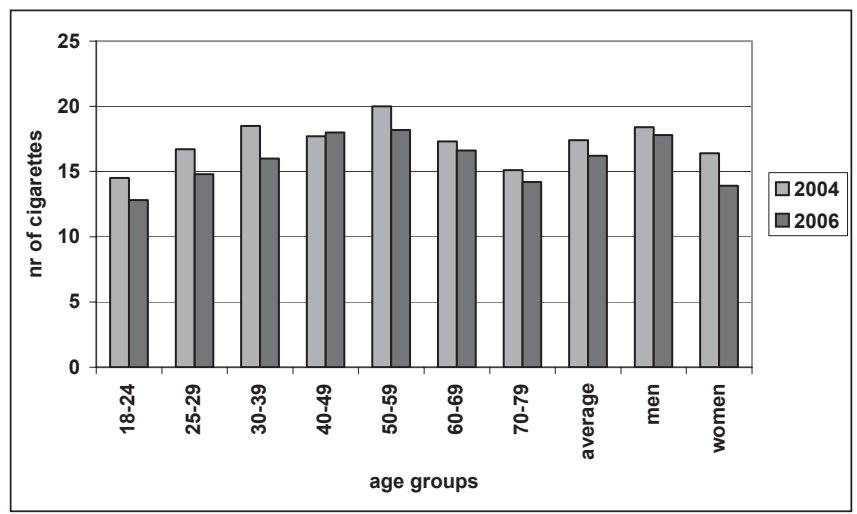

Fig. 2. Daily consumption of cigarettes per smoker (2004 and 2006)

(Source: Hungarian Gallup Institute) 
women smokers (cca 1 million) decreased their consumption by 912 million cigarettes per year, while the overall decrease among adult men smokers (cca 1.6 million) has been 350 million pieces per year, giving a total of 1.262 billion less smoked cigarettes.

Price elasticity expresses the impact on consumption of a $10 \%$ increase in cigarette retail prices. According to GKI, the price elasticity of tobacco products in Hungary can be put between -0.44 and -0.37 , which is comparable with price elasticities of developed countries (2). This means that a $10 \%$ cigarette price increase in Hungary results in an around $4 \%$ decrease in consumption.

\section{Black Market}

There are controversial data on the share of the illicit trade of cigarettes in the overall Hungarian cigarette market. The figures largely depend on the source of data. The customs office puts the level of the black market between $5-10 \%$ (13), while tobacco industry sources talk about $25 \%$ (5).

Available hard statistical data on seizures and confiscations regularly published by the Hungarian Customs and Finance Guard (CFG) (14) can prove that figures tobacco industry uses are exaggerated and the real share of cigarette black market is much lower than that (Table 5).

\section{DISCUSSION}

This analysis presents data collected from Hungarian sources to prove the relationship between the taxation of tobacco products, consumption and state incomes from the tobacco sector. The World Bank has performed similar economic analyses for a number of countries (15). All of them concluded that tobacco tax increases reduce consumption, and, at the same time, increase government revenue. In 2006, Gallus et al. prepared an extensive analysis of the relationship between price and consumption for the 52 countries of the WHO European region and also proved the inverse relationship between cigarette price and consumption (16).

Hungarian data support findings from other countries claiming a positive impact of higher tobacco taxes on health. In addition to that, Hungarian figures indicate that tax increases do not harm the country's economy, and, if the amount of collected tax declines that can only be attributed to drastic counter-measures taken by tobacco companies.
Taxation is not the sole determinant of cigarette retail prices (production costs, retail margins being other influencing factors). Thus, there is ample room for tobacco companies to manipulate cigarette prices. In Hungary, as a response to tax hikes companies responded by decreasing their retail margins, generating "price wars" or introducing discount brands. Tobacco companies also make continuous efforts to prevent the Hungarian government from imposing higher taxes on cigarettes $(5,17,18)$. The main aim of the industry is to keep tobacco products affordable to smokers (19). Industry measures against higher taxes not only negatively influence health by keeping smokers addicted and mitigating the impact of tax increases, but also cause lost tax revenues to the state budget.

Regular tax increases performed by consecutive Hungarian governments succesfully decreased the demand for tobacco products. Even the tobacco industry admits that higher taxes are largely responsible for the decreasing consumption observed since 1998. "The phenomenon [the decrease of overall cigarette consumption] is primarily caused by social, cultural and economic factors, especially by tax raises surpassing inflation, and this trend could have not been reversed by any intensive campaign", Andras Patai, president of the Hungarian Association of Cigarette Manufacturers said in an interview in 2002 (20). Tobacco control professionals should therefore advocate for higher cigarette taxes to complement other key interventions aimed at curbing tobacco use.

When raising cigarette taxes, adequate measures to control cigarette smuggling also have to be taken. Tobacco companies only blame high cigarette prices as the cause of smuggling. European experience indicate that price alone does not explain the level of smuggling (21). Another important factor influencing smuggling is the level of corruption which afflicts a particular country, represented by the so-called transparency index (22).

It is in the interest of tobacco companies to exaggerate their prediction about the escalation of illicit trade when governments contemplate cigarette tax increases. This industry tactic could deter governments and parliamentarians from introducing effective tax policies. Tobacco companies also exaggerate when estimating the volume of the Hungarian black market.

So far there are no reliable data on the cigarette black market in Hungary. Estimates largely depend on the source. The CFG collects data on the volume of discovered and confiscated cigarettes. The amount of smuggled cigarettes eventually sold on the Hungarian market is, however, difficult to estimate. Both the

Table 5. Amount of confiscated/discovered cigarettes* and their market shares. (Source: CFG data)

\begin{tabular}{|l|c|c|c|c|c|}
\hline Year & $\begin{array}{c}\text { Cigarettes sold } \\
\text { legally } \\
\text { (million pieces) }^{* *}\end{array}$ & $\begin{array}{c}\text { Cigarettes confis- } \\
\text { cated by CFG } \\
\text { (million pieces) }\end{array}$ & $\begin{array}{c}\text { \% of confiscated cigarettes/ } \\
\text { legal market+confiscated } \\
\text { cigarettes }\end{array}$ & $\begin{array}{c}\text { Counterfeit cigarettes } \\
\text { discovered by CFG } \\
\text { (million pieces) }\end{array}$ & $\begin{array}{c}\% \text { of discovered smug- } \\
\text { gled cigarettes/legal } \\
\text { market+discovered cigarettes }\end{array}$ \\
\hline 2000 & 21,968 & 80 & 0.36 & 169 & 0.76 \\
\hline 2001 & 19,940 & 213 & 1.05 & 289 & 1.43 \\
\hline 2002 & 19,006 & 109 & 0.57 & 194 & 1.01 \\
\hline 2003 & 19,715 & 112 & 0.57 & 165 & 0.85 \\
\hline 2004 & 15,628 & 181 & 1.14 & 283 & 1.78 \\
\hline 2005 & $13,500^{\star * *}$ & 278 & 2.02 & 360 & 2.60 \\
\hline
\end{tabular}

*confiscated cigarettes=amount of smuggled cigarettes which physically entered into the possession of the CFG; discovered cigarettes=confiscated cigarettes+the volume of counterfeit cigarettes the CFG knows information about as a result of the investigation, but never entered physically into its possession;

${ }^{* *} \mathrm{GKI}$ Economic Research Institute,

***Népszabadság, http://nol.hu/cikk/428249/ 
industry and anti-smoking advocates have their own estimates. In late 2005 an undisclosed tobacco industry source leaked to the press the findings of a survey, which concluded that that the second most smoked "Hungarian brand" is the Ukraine-produced Priluki (a Ukrainian brand of BAT). The „research” was based on the collection of discarded empty cigarette boxes found in the streets (23).

In 2005, the National Epidemiologic Centre performed a survey in Baranya county (in the southern part of Hungary), where the question aimed at estimating the volume of smoked cigarettes originating in the black market was: "Where did you buy the tobacco product/pack of cigarettes you use just now? " There were three answers given (in the market, on the street or from a friend, an acquaintance, a person), which could imply a nonlegal source. Only $1 \%$ of respondents acknowledged a non-legal source even when the question did not include a direct reference to cigarette smuggling (24).

Irrespective of the level of smuggling tax policies should be implemented in parallel with policies aimed at preventing and controlling cigarette smuggling. The Hungarian Government provides funding for special mobile units ("cigarette commandos") of the CFG strengthening its capacities to control cigarette smuggling. In May 2006 Hungary joined the agreement between the European Union and Philip Morris International (PMI), based on which the tobacco company is made (financially) liable for the emerging of smuggled cigarettes under its brand names in Member States (25). Joining international efforts to combat global cigarette smuggling under the auspices of the FCTC is also advisable.

Tobacco control advocates should make efforts to inform their governments, and especially, finance ministries that tobacco tax increases are important measures to improve health, that these do not harm the economy, and the cigarette black market is a problem which can be controlled.

\section{Acknowledgements}

The research on which this paper is based was funded by an unrestricted grant from Pfizer Kft (Hungary) to Dr Tibor Szilágyi in 2006.

\section{REFERENCES}

1. Jha P, Chaloupka FJ. Curbing the epidemic: governments and the economics of tobacco control. Washington D.C.: The World Bank; 1999.

2. Barta J, Szilágyi T, Tompa T. Social costs of smoking and the impact of tobacco excise duties [manuscript]. Budapest: 2006. (In Hungarian.)

3. Ross H. The economics of tobacco and tobacco control in the European Union. In: European Commission. Tobacco or health in the European Union: past, present, future. Luxembourg: Office for Official Publications of the European Communities; 2004. p. 70-99.

4. European Commission [homepage on the Internet]. Brussels: Taxation and Customs Union [cited 2007 Feb 20]. Tobacco products legislation. Available from: http://ec.europa.eu/taxation_customs/taxation/excise_duties/tobacco_products/legislation/index_en.htm.

5. The International Tax and Investment Center (IT1C) [homepage on the Internet]. Oxford: Oxford Economic Forecasting [cited 2007 Feb 20]. Addressing the EU cigarette excise regime review 2006. Available from: http://www.iticnet.org/SeminarEUTobaccoTaxation/ EU\%20II\%20Paper\%202006.pdf.

6. Magyar Hírlap [homepage on the Internet]. Tobacco - business with no limits for all: 2004 July 14 [cited 2007 Feb 20]. Available from: http:// www.magyarhirlap.hu/cikk.php?cikk=85559. (In Hungarian.)
7. The World Bank [homepage on the Internet]. Economics of tobacco for the Europe and Central Asia (ECA) region. 2001 May 20 [cited 2007 Feb 20]. Available from: http://siteresources.worldbank.org/INTETC/ Resources/375990-1089913200558/EasternCentralAsia.pdf.

8. Guindon GE, Tobin S, Yach D. Trends and affordability of cigarette prices: ample room for tax increases and related health gains. Tob Control. 2002 Mar;11(1):35-43.

9. Encyclopaedia Britannica [homepage on the Internet]. Hungary: Bokrospackage [cited 2007 Feb 20]. Available from: http://www.britannica. com/eb/article-9112756/HUNGARY.

10. FACT Institute of Applied Sciences. Tobacco smoking and alcohol consumption: facts and opinions among the Hungarian public. Pécs: Fact; 1999. (In Hungarian.)

11. The Gallup Organization [homepage on the Internet]. Budapest: Hungarian Gallup Institute [cited 2007 Feb 20]. Smoking in the Hungarian public 1995-2000-2004. Available from: http://www.google.cz/search? $\mathrm{hl}=\mathrm{cs} \& \mathrm{q}=\% 28 \mathrm{Doh} \% \mathrm{C} 3 \% \mathrm{~A} 1$ nyz $\% \mathrm{C} 3 \% \mathrm{~A} 1 \mathrm{~s}+\mathrm{a}+$ magyar + lakoss $\% \mathrm{C} 3 \% \mathrm{~A}$ $1 \mathrm{~g}+\mathrm{k} \% \mathrm{C} 3 \% \mathrm{~B} 6 \mathrm{r} \% \mathrm{C} 3 \% \mathrm{~A} 9 \mathrm{ben}+1995-2000-2004 \& \mathrm{btnG}=\mathrm{Hledat} \& 1 \mathrm{r}=$. (In Hungarian.)

12. The Gallup Organization [homepage on the Internet]. Budapest: Hungarian Gallup Institute [cited 2007 Feb 20]. ODE Smoking Monitor 2006. Available from: http://health21.hungary.globalink.org/pecs_2007majus16/gallup_monitor_2006.pdf. (In Hungarian.)

13. Félix P. I would rise the price of cigarettes to the heaven. Magyar Narancs. 2002 Aug 8;14(32). (In Hungarian.)

14. Hungarian Customs and Finance Guard [homepage on the Internet]. Budapest: HC\&FG [cited 2007 Feb 20]. Cigarette smuggling. Available from: http://vam.gov.hu/viewBase.do? elementId=5100\&modulId=2. (In Hungarian.)

15. The World Bank Group [homepage on the Internet]. Washington, D.C.: Economics of Tobacco Control [cited $2007 \mathrm{Feb} 20$ ]. Country \& regional profiles and economics of tobacco briefs. Available from: http://www1. worldbank.org/tobacco/countrybrief.asp.

16. Gallus S, Schiaffino A, La Vecchia C, Townsend J, Fernandez E. Price and cigarette consumption in Europe. Tob Control. 2006 Apr;15(2):114-9.

17. British American Tobacco [homepage on the Internet]. Budaörs: BAT Hungary [cited $2007 \mathrm{Feb} 20$ ]. Pécs tobacco factory will not close. BAT press release $2004 \mathrm{Feb} 5$. Available from: http://www.bat.hu/oneweb/sites/BAT 57KCC3.nsf/0/066b69d8a407e2c580256e37003b6f57?OpenDocument. (In Hungarian.)

18. Ceebiz.com [homepage on the Internet]. Portrait of Pauline Stam [cited 2007 Feb 20]. Available from: http://www.ceebiz.com/user/article. asp?articleid $=192975$.

19. Szilágyi T, Chapman S. Tobacco industry efforts to keep cigarettes affordable: a case study from Hungary. Cent Eur J Public Health. 2003 Dec;11(4):223-8.

20. Kreativ [homepage on the Internet]. With unchanged heat. Tobacco market after the introduction of the advertising ban [cited 2007 Feb 20]. Kreatív. 2002 May 31. Available from: http://www2.kreativ.hu/cikk.php?id=6358. (In Hungarian.)

21. Joossens L, Raw M. Cigarette smuggling in Europe: who really benefits? Tob Control. 1998;7(1):66-71.

22. Merriman D, Yurekli A, Chaloupka FJ. How big is the worldwide cigarette smuggling problem? In: Jha P, Chaloupka FJ, editors. Tobacco control in developing countries. Oxford: Oxford University Press; 2000. p. $365-$ 92.

23. Népszabadság [homepage on the Internet]. Mihálovits A. A market leader from a smuggled brand [cited 2007 Feb 20]. Népszabadság. 2006 Jan 7. Available from: http://nol.hu/cikk/389889/. (In Hungarian.)

24. Kéki Zs. Survey findings of a 2005 Baranya county survey [personal communication]. Budapest: National Center for Epidemiology; 2005. (In Hungarian.)

25. European commission [homepage on the Internet]. Brussels: European Community [cited 2007 Feb 20]. Anti-contraband and anti-counterfeit agreement and general release, dated as of July 9, 2004. Available from: http://ec.europa.eu/anti_fraud/budget/agreement.pdf. 